\title{
APPLICATION OF MATHEMATICAL PROBLEMS AS MEANS OF IMPLEMENTING COMPETENCY-BASED APPROACH
}

\author{
PROBLEMAS MATEMÁTICOS DE APLICAÇÃO COMO UM MEIO DE \\ IMPLEMENTAR UMA ABORDAGEM BASEADA NA COMPETÊNCIA
}

\author{
PROBLEMAS MATEMÁTICAS APLICADAS COMO INSTRUMENTOS DE USAR \\ ENFOQUE BASADO EN COMPETENCIAS
}

\author{
Maria E. CHEKULAEVA ${ }^{1}$ \\ Natalia V. SIDOROVA ${ }^{2}$ \\ Natalia G. KUZINA ${ }^{3}$ \\ Julia A. VESELOVSKAYA ${ }^{4}$
}

\begin{abstract}
Having included the list of general and professional competencies in the educational standards, the significant difficulties occurred in their formation and measurement of the level of their achievement in teaching mathematics. The aim of this work is to develop a set of application mathematical problems aimed at the formation of both the skills in the subject and certain competencies of the students of the secondary professional institutions. The theoretical research formed the methodological basis. It consists of the theory of competency-based approach, theory of problem solving and applied direction of the course of mathematics. The main directions of creating the complex of application tasks, the content of which has professional orientation, were also defined. The practical part of the study is to determine the content of application tasks in a dedicated professional field, justifying the influence of applied professional-oriented tasks on the formation of general competencies in students. The efficiency of the developed complex of application tasks was estimated during the pedagogical experiment. The results show that this complex promotes both in-depth study of mathematics and the formation of a certain group of competencies in students. The complex is applied in educational process of Ulyanovsk College of Food and Trade. The data of the study can be useful for teachers of mathematics of the secondary professional institutions.
\end{abstract}

KEYWORDS: Competency-based approach. General competencies. Application task.

RESUMO: Tendo incluído a lista de competências gerais e profissionais nos padrões educacionais, as dificuldades significativas ocorreram em sua formação e medição do nível

\footnotetext{
${ }^{1}$ Ulyanovsk State Pedagogical University, Ulyanovsk - Russia. Senior Lecturer. ORCID: https://orcid.org/00000003-0236-5137. E-mail: metodmatem@mail.ru

${ }^{2}$ Ulyanovsk State Pedagogical University, Ulyanovsk - Russia. Senior Lecturer and Head of the Methods of Mathematical and Information Technology Education Department. ORCID: https://orcid.org/0000-0002-75655226. E-mail: navsi69@mail.ru

${ }^{3}$ Ulyanovsk State Pedagogical University, Ulyanovsk - Russia. Senior Lecturer and Dean of the Faculty of Physics and Mathematics and Technology Education. ORCID: https://orcid.org/0000-0003-1707-4383. E-mail: metod-matematika@yandex.ru

${ }^{4}$ Ulyanovsk State Pedagogical University, Ulyanovsk - Russia. Senior Lecturer. ORCID: https://orcid.org/00000003-3381-3211.E-mail: veselovskaya.yulya@bk.ru@mail.ru
} 
de seu desempenho no ensino da matemática. O objetivo do trabalho é desenvolver um conjunto de problemas matemáticos de aplicação visando a formação tanto das habilidades na matéria, quanto de certas competências dos alunos das instituições profissionais secundárias. A pesquisa teórica formou a base metodológica. Ela consiste na teoria da abordagem baseada na competência, teoria da resolução de problemas e direção aplicada do curso de matemática. Também foram definidas as principais direções de criação do complexo de tarefas de aplicação, cujo conteúdo tem orientação profissional. A parte prática do estudo consistem em determinar o conteúdo das tarefas de aplicação em um campo profissional dedicado, justificando a influência das tarefas aplicadas de orientação profissional na formação das competências gerais dos estudantes. A eficiência do complexo desenvolvido de tarefas de aplicação foi estimada durante a experiência pedagógica. Os resultados mostram que este complexo promove tanto o estudo profundo da matemática quanto a formação de um determinado grupo de competências nos estudantes. O complexo é aplicado no processo educacional do Colégio de Alimentos e Comércio de Ulyanovsk. Os dados do estudo podem ser úteis para os professores de matemática das instituições profissionais secundárias.

PALAVRAS-CHAVE: Abordagem baseada na competência. Competências gerais. Tarefa de aplicação.

RESUMEN: La inclusión de la lista de competencias generales y ocupacionales en estándares educativos causa mayores dificultades en cuanto a formarlos y medir el nivel de estas competencias alcanzado en la enseñanza de matemáticas. Aquí se tiene por objetivo desarrollar un conjunto de problemas matemáticos aplicados destinados a formar capacidades de materia y ciertas competencias en estudiantes de centros de formación secundaria profesional. La parte teórica de la investigación ayuda a definir la base metodológica, incluyendo el enfoque basado en competencias, la teoría de solver problemas y la orientación aplicada del curso en matemáticas; identificar las vías principales de crear un conjunto de problemas aplicadas con un contenido de orientación ocupacional. La parte práctica de la investigación consiste en definir el contenido de problemas ocupacionales en una esfera particular y medir la influencia de problemas aplicadas de orientación ocupacional en la formación de competencias generales en los estudiantes. La eficacia del conjunto desarrollado de problemas aplicados fue evaluada por medio de un experimento pedagógico. Los resultados permiten decir que este conjunto facilita una comprensión más profunda de matemáticas y la formación de un cierto grupo de competencias en los estudiantes. Se usa el conjunto en el proceso educativo en la Escuela de Peritaje de Alimentación y Comercio de Ulianovsk. Los materiales de la investigación pueden ser útiles para maestros de matemáticas en centros de formación secundaria profesional.

PALABRAS CLAVE: Enfoque basado en las competencias. Competencias generales. Tarea de aplicación.

\section{Introduction}

One of the components of training a modern specialist is acquiring general (universal) competencies, which is a set of basic knowledge and super subject skills, and certain personal traits necessary for a productive professional activity. The standard of secondary professional

RPGE- Revista on line de Política e Gestão Educacional, Araraquara, v. 25, n. esp. 1, p. 713-725, mar. 2021 e-ISSN:1519-9029 
education includes a certain set of such competencies. In this case, the educational standard (for example, for the "Merchandising and expert quality control of consumer goods") (Federal state educational standard) provides a set of both general and specific professional competencies. Eight general and two professional competencies are mentioned in this paper. Analysis of the content of coursebooks on mathematics for this institutions (BASHMAKOV, 2014; BOGOMOLOV; SAMOYLENKO, 2015) shows that the content is not focused on a certain type of professional activity, contains very few tasks aimed at formation of the competencies mentioned in the standard. The analysis of mathematics teachers experience in the secondary professional educational organizations shows that the process of implementing the requirements of the standard is rather slow and problematic.

The importance of resolving the conflict between the requirements of the educational of secondary professional education to the formation of certain professionally significant competencies in students and insufficiently developed substantive basis for this implementation substantiate the relevance of this study.

The problem of the study is finding what methodological bases of teaching mathematics that contributing to the formation of general competencies of students of organizations of secondary vocational education?

Currently, the work of many teachers deals with solving this problem. Different authors offer different methods, like discussions, round tables, weeks of mathematics, etc. Many researchers mention the role of application tasks in the formation of professional and general competencies while studying mathematics (KOSTROVA, 2014). However, it is necessary to recognize currently application problems are not included in mathematical education and are compiled outside any system. Despite the fact that the application problems positively affect the formation of both general and professional competencies, a set of such problems is not yet developed. This set should allow purposefully forming the competencies specified in educational standard, as well as to serve as a measuring material for determining the level of mastery of discipline and acquired competencies.

The aim of this research is to develop a set of application mathematical problems aimed at the forming the common competencies in students of secondary professional organizations.

\section{Materials and methods}

During first years students study general disciplines. Mathematics occupies a 
significant place among them. In this period of study, students do not see and cannot realize the role of mathematics in professional activities. Therefore, the problem is not only to show students the importance of mathematics in any field of activity, but also to create conditions for their mastering corresponding general competencies. The acquisition of competencies in the scope, which is possible within the framework of the academic discipline, aids further professional growth of a student.

One of the methods of forming general competencies is solving application problems. The content of these problems allows acquiring some experience of applying knowledge in professional activity. It promotes the mastery of general competencies. However, the problems that are aimed not only at increasing the students' knowledge about the fields of mathematics application, but also in the partial imitation of the improvised working situation, are very few. Moreover, there are no problems aimed at forming general competencies in specific training profiles.

The term "application problem" in the scientific literature does not have an unambiguous definition. In this paper, the authors lean on the definition by Tereshina N.A.: "the application problem is a problem put outside mathematics and solved by mathematical methods" (MOZHAEV, s/d). As a rule, it has scientific (practical) significance both in mathematics and other fields. The process of solving the application problems is divided into such stages as formalization (translation of content from natural language to mathematical, i.e. mathematical model development); solution of the problem within the model; interpretation of the decision made (MOZHAEV, s/d).

The characteristics of applied tasks are distinguished. One of the most recognized characteristics of such problems is their focus on the formation of the ability to apply knowledge in real situations. Recently, they developed application problems for the situations from different fields of activity. All of them are aimed at developing the interest in mathematics and thinking: the ability to "see" mathematical models in different situations. From the viewpoint of the competency-based approach, the application tasks are to not only increase the knowledge of students about the application of mathematics in different spheres of activity, but first of all, be directed on forming the competencies mentioned in the standard of education for this specialty. However, the focus of these problems on the formation of certain traits (i.e. the acquisition of specific competencies) is currently underdeveloped. This is because of many reasons. One is that the search and selection of content for these problems requires special knowledge in the field of professional orientation of an educational organization.

RPGE- Revista on line de Política e Gestão Educacional, Araraquara, v. 25, n. esp. 1, p. 713-725, mar. 2021. e-ISSN:1519-9029 
The scientific and methodological literature has application problems that are professionally oriented. They describe certain professional situations (DVULICHANSKAYA, 2007). It is necessary to recognize the worth of their content. They really allow developing students' interest in a profession, as well as their thinking. However, these problems should also form certain personal traits, i.e. competencies.

Here, the authors chose the following formed competencies: GC1 (to understand the essence and social importance of the future profession and show steady interest in it) and GC4 (to search and use the information necessary for efficient performance of professional tasks, professional and personal development). This choice is justified by the fact that during the first year, the students learn the general disciplines. This means the students are not the fully aware of their professional choice. GC1 implies the development of interest in the profession, GC4 - the expansion of students' ideas about the essence of the profession and professional development.

Application problems in vocational education may be divided into two groups:

1) Those that use the concepts and terms for giving social meaning to mathematical concepts. They increase motivation for studying and develop interest in both mathematics and the profession, i.e. they form $\mathrm{GC} 1$.

2) Those that put the student in a professional situation that requires the use of mathematical methods. These tasks not only develop the thinking, but also form the GC4, i.e. to use information for solving professional problems. All this promotes professional growth.

Any educational task (an application problem is an educational task) should not only develop the ability to apply knowledge in different situations, but also to control how the given skill is formed. Therefore, if talk about the purpose of application problems, the tasks should be a material for diagnostics of both skills and level of acquired competence within the educational discipline. Competencies are manifested in activity, therefore the applied task should contain a part of this activity, in which the student solves a professional problem by mathematical methods. One problem or a set of similar tasks cannot completely form a planned competency, but can form its certain part of the competence in a trainee during the solution of the problem is quite possible.

In order to quantify the reliability of the research results, the authors conducted a pedagogical experiment for five years (2013-2017) in the Ulyanovsk College of Food and Trade, with participating teacher of mathematics Dedushkina Tatyana Petrovna and the 
authors of this paper as teachers. In total, 386 students of specialty "Commodity and Expertise of Consumer Goods" participated in the experiment.

During the ascertaining experiment the authors carried out an analysis of the documents illustrating the program of mathematical education at the first and last years, as well as perform the initial evaluation of the influence of the course of mathematics on the formation of certain competencies in students. The results of this stage of the experiment showed that the study of mathematics has a small impact on the formation of the abovementioned competencies, but it is aimed only at assimilation of the subject knowledge and skills. The analysis of questionnaires filled by the students at the end of the first year in 2013 justified that mathematics lessons from purely mathematical skills and is not connected (in students' opinion) with the future professional activity. Only five of the 50 students indicated that mathematics is needed in the profession of merchandiser. The rest stated that "a merchandiser should be able to use the calculator to count and should not know the different functions and properties of geometric objects".

The search experiment tested various variants of adjustment of the content of some topics related to the specialty. In 2014-2015 academic years the scope of the topic "Basics of probability theory" was complemented with examples of calculations used in merchandising. The results of the diagnosis of the level of knowledge and competencies showed that this method helps students to acquire the above-mentioned competencies. On this basis the content of some topics of the course of mathematics was developed with due regard to professional peculiarities of the specialty. The most expedient content was the application problems. At this stage the authors selected relevant material and compiled application problems. The problems were separated according to the topics of the course and developed a system that allowed not only to form the intended competencies in students, but also to assess the level of acquired competencies.

Implementation of the developed educational material (in the form of collected application problems in mathematics) and methodological data was carried out in 2016-2017. Diagnostics of the level of acquired competencies of $\mathrm{GC} 1$ and $\mathrm{GC} 4$, as well as mathematical knowledge and skills, was carried out regularly both in experimental training (195 people) and control (193 people) groups. The training groups used mathematical application problems, while in the control group the classes were conducted according to the usual teaching method. The authors took the following diagnostic indicators: average score for this subject and the average score for the level of competency to which the points are attributed. They indicated the zero level -0 points, low level -1 point; average level -2 points, and high 
level -3 points. The reliability of the experiment results was determined by the Student $t-$ criterion, which indicates how many times the difference between the average valuesis more is compared to their error. The differences in the average reliability score were the following: The value of the average error $t=3.4$, its boundary value $\operatorname{tg}=2.1$. Since $t>t p$, it is possible to say that the the proposed methodology (especially a set of application mathematical problems with professional content) aimed at improving the quality of knowledge and skills and the formation of competencies is efficient.

\section{Results}

The development of the set and the compilation of the application problems showed that such problems should have the structure of the educational task (condition-operatorrequirement), context (the description of some professional situation (problem), which is considered from the mathematical point of view), and the competency component (aimed at forming a certain competency) (CHEKULAEVA, 2015).

Let us consider some examples of the problems included in the set.

Task 1. "The location of the display racks in the trading hall is possible in the following variants: "rake", "grid", "diagonal" (the schemes are provided) Calculate the largest number of racks fitting into this room for each variant; calculate the "lost area"; select the most expedient variant of racks arrangement for this trading hall.

From the conditions of the problem it becomes clear that the solution engages the student in an improvised working situation. It creates a condition for formation of GC1 (to realize importance of the future professional activity) in the forms of selecting the convenient arrangement of the equipment with due regard to the comfort of buyers and sellers. It also forms the GC4 - to choose the necessary information from a task condition in order to get the best solution, the rationale for choosing the most convenient option. In solving this problem, the student uses mathematical knowledge (formulas used in solving quadrangles, parallelograms, trapeze, etc.) and develops the ability to apply this knowledge in different situations.

Task 2. «Calculate the buyer's way from the entrance of the store to the dairy department, to the cashier, and to the exit. Find the sides of the obtained triangle, its angles, and its perimeter". The task has the variants of trading halls with different locations of the dairy department. In this case, the acquisition of the $\mathrm{GC} 1$ is also visible (awareness of the most convenient placement of the department to raise the greatest interests in buyers). The 
consideration of different options of the department's location in different trading halls, and other information like different sizes of the trading hall and placement of departments, creates the conditions for the formation of GC4.

While studying other sections of mathematics, for example, the function with derivatives, the authors proposed problems for calculating profits, the number of sales, the dynamics ofinventory turnover, etc. The compilation of such problems uses the data of supervision over the work of the trading enterprise, i.e. all the values specified in the problem are real. For example, the data of the actual observation of the activity of a trading company (store) may be used for calculating the dependence of the number of sales of piece goods from time. It turned out that the number of sales changes in approximation of complex functions that can be represented as ordinary mathematical dependencies. The condition of such problems is accompanied by visual materials, like observed dependence of the number of sales from time, and approximate kind of mathematical dependence corresponding in some approximation of real dependence.

The use of application problems leads to the development of the structure of the lesson, in which the special place is occupied by solving these problems in order to form skills and competencies, as well as performing their diagnosis. The study defines the place of this type of problems in the structure of the lesson. At the stage of perception of the new element of knowledge (new material), the application task (simple in complexity) is offered to students for the initial fixation of knowledge at the end of the lesson. In this case, the diagnosis of skills and competencies may not be carried out. In the lesson of the formation of a skill to solve a certain class of mathematical problems, application problems alternate with purely mathematical ones. Mathematical problems train automatic actions, while application tasks develop the application of skills in new situations.

In this study, the level of competency achievement was determined on a four level scale (zero, low, medium, high levels). Each person is granted a certain number of points $(0$, $1,2,3)$. The level criteria are as follows:

For GC1: zero level means that a student can't solve the problem; low level - the student makes a mathematical model of the situation with the help of a hint; average level - a student solves a problem, but does not substantiate the decision from a professional point of view; high level - a student solves the problem and substantiates the decision from a professional point of view.

For GC4: zero level - a student cannot create a mathematical model of the problem; low level - a student creates the mathematical model of the described situation, but does not 
find the information that allows to substantiate it; average level - a student creates a mathematical model of the situation, solves the problem, finds additional information for the professional substantiation of the solution; high level - a student creates a mathematical model, solves the problem, finds additional information for the professional substantiation of the solution, and independently compiles a similar task.

\section{Discussion}

Theoretical research methods consisted in the analysis of scientific works, methodological and educational literature, and normative documents on the studied problem.

The methodological basis of the study is formed by the theory of the competencybased approach (A.V. Khutorskoy, I.A. Zimnyaya, O.E. Lebedev, V.V. Kraevsky, etc.), the theory of training tasks (G.A. Ball, O.K. Tikhomirov, L.M. Fridman, etc.), and the research on the applied mathematics (N.Y. Vilenkin, V.A. Gusev, A.N. Kolmogorov, N.A. Tereshin, etc.).

The competency-based approach is the basis of modern education. The concepts of competency and competence are defined, and the classifications of competencies are created (KRAEVSKY, 2005; LEBEDEV, 2004; RUDANETS, s/d; ZIMNYAYA, 2013). The educational standard is based on this approach (KHUTORSKOY, s/d). Distinguishing the concepts of competency and competence is based on the allocation of such attributes as internal and external human worlds. Competency is a social requirement for educational training. Competence is a possession of the relevant competence. Such concepts as competency-based education, professional competence, key competencies are disclosed and clarified in scientific and methodological literature. The structuring of an educational process that promotes the acquisition of professional competencies in the study of general education disciplines (especially, the science disciplines) is substantiated. The educational and methodological complex that allows implementing competency-based approach is offered (BELYASNIKOVA， 2015; DVULICHANSKAYA，2007; 2011; SIDOROVA， 2015; CHEKULAEVA; SIDOROVA, 2017). Kamaleeva (2016) allocates competency-based content of an educational discipline in modular-competency-based approach. Thus, the implementation of the competency-based approach in the secondary professional education is carried out differently. However, the most promising is solving application specialty-oriented problems.

The methodological basis for identifying the solution of application problems in the study of mathematics as the leading idea for the formation of general competency is the work 
of E.A. Ball (1990). He considers the problem as a definite system, the components of which are the subject and model. Another researcher is Fridman (1977), who considered the psychological aspect of solving problems and defining the problem as a sign model of the problem situation. The questions of controlling thinking activity in solving problems are considered in the work by Tikhomirov (1984).

Mikhaylova (1998) considered the dependence of the formation of competency on the relative share of applied professionally oriented material in the content of the training course. Kudryavtseva (2011) shows the feasibility of using the application problems in the educational process in forming general competencies in students. The analysis of published works justifies that the application problems play an important part in the formation of competencies (CHEKULAEVA, 2015; FAZLEEVA, 2013; RUDANETS; TERESHIN, 1990).

\section{Conclusion}

The assessment of the impact of the developed set of application problems on the acquisition of competencies by students was carried out during the pedagogical experiment conducted in the Ulyanovsk College of Food and Trade for five years. The reliability of the results was determined by the statistical methods. It confirmed the positive effect of application problems on the level of competency formation. The experimental results also showed interesting dynamics of formation of the above-mentioned competencies. GC1 (understanding the essence of the profession and interest in it) did not increase at the beginning of training in experimental groups. Discussing this problem with the students revealed that at the first lessons in mathematics many application problems seemed to be difficult and unfamiliar. The students did not even start solving them. Later, the problems aroused a sustainable interest. There was a desire to solve as many of them as possible. Moreover, the students showed great ingenuity in finding different professional situations and compiling new problems. After two months of training, the dynamics of the level of competency formation in the experimental groups began to grow by linear dependence. The control groups also solved application problems, but from other sources, not related to the formation of the above competencies. In these groups, the level of competency formation remained at a low level for more than six months, and then increased slowly, much slower than in the training groups.

The obtained results allow building a strategy of teaching mathematics aimed at mastering the subject knowledge and skills, as well as acquiring competencies and measuring 
the level of their achievement. The content of the set of application problems, corresponding to the topics of the course of mathematics and specificity of the future professional activity of students was determined based on the research results.

\section{Recommendations}

The developed set of application problems can be useful to teachers of mathematics of the general professional educational institutions.

\section{REFERENCES}

BALL, G. A. Teoriya uchebnykh zadach: psikhologo-pedagogicheskiy aspekt [Theory of educational problems: Psychological and pedagogical aspect]. Moscow: Pedagogika, 1990.

BASHMAKOV, M. I. Matematika: uchebnik dlya studentov uchrezhdeniy srednego professional'nogo obrazovaniya [Mathematics: coursebook for institutions of secondary professional education]. Moscow: Akademia, 2014.

\section{BELYASNIKOVA, A.N. Osobennosti otsenivaniya sformirovannosti kompetentsiy u} studentov kolledzha [Features of assessing the competency formation in college students]. 2015.

BOGOMOLOV, N. V.; SAMOYLENKO, P. I. Matematika: uchebnik dlya SPO

[Mathematics: coursebook for institutions of secondary professional education]. 5th ed. Moscow: Izdatel'stvo Yurayt, 2015.

CHEKULAEVA, M. E. Nekotorye osobennosti kompetentnostnogo podkhoda v uchebnom protsesse po fizike [Some features of the competency-based approach in teaching physics]. In: RUDAKOVA, I. A. (Ed.). Sovremennaya nauka: teoreticheskiy i prakticheskiy vzglyad: proceedings of the II International research and practice conf. Moscow: Izdatel'stvo "Pero", 2015.

CHEKULAEVA, M. E.; DEDUSHKINA, T. P. Real'nye professional'no orientirovannye matematicheskie zadachi - sredstvo formirovaniya u obuchayushchikhsya srednikh obrazovatel'nykh organizatsiy obshchikh professional'nykh kompetentsiy [Real specialtyfocused mathematical problems as the means of forming general professional competencies in students of secondary educational institutions]. In: INTERNATIONAL FORUM ON THE ISSUES OF SCIENCE, TECHNOLOGY AND EDUCATION, 19., 2015, Moscow. Proceedings [...]. Moscow: Akademiya nauk o Zemle, 2015.

CHEKULAEVA, M. E.; SIDOROVA, N.V. Kompleks zadach s tekhnicheskim soderzhaniem kak sredstvo rasshireniya osvedomlennosti uchashchikhsya o printsipe raboty sovremennoy tekhniki [A complex of problems with technical content as a means of increasing students' awareness of the principle of the operation of modern technology]. In: SHAKIROVA, L. R.; LOBACHEVSKY, N. I. (Ed.). i matematicheskoe obrazovanie v Rossii: proceedings of the 
International forum on mathematical education. Kazan': izd-vo Kazan., un-ta, 2017. v. 2.

DVULICHANSKAYA, N. N. Didakticheskaya sistema formirovaniya professional'noy kompetentnosti studentov srednego professional'nogo obrazovaniya $v$ protsesse estestvenno-nauchnoy podgotovki [Didactic system of forming professional competency in students of secondary professional education in the process of training in science]. (Extended abstract of candidate dissertation). Moscow: Bauman Moscow State Technical University, 2011.

DVULICHANSKAYA, N. N. Osobennosti izucheniya professional'no znachimykh voprosov khimii elementov v uchrezhdeniyakh srednego professional'nogo obrazovaniya [Features of studying professionally significant issues of chemistry in institutions of secondary professional education]. In: SIDOROVA, N.V. (Ed.). Aktual'nye problemy khimii i metodiki ee prepodavaniya. Nizhny Novgorod: Izd-vo NGPU, 2007.

FAZLEEVA, E. I. Kompetentnostnyy podkhod v obuchenii matematike [Competency-based approach in teaching mathematics]. Nauchnoe obozrenie, Seriya 2: Gumanitarnye nauki, n. 1-2, p. 79-83, 2013.

RUSSIA. Federal state educational standard of secondary professional education. Available: https://минобрнауки.рф/документы/923. Access: 10 oct. 2020.

FRIDMAN, L. M. Logiko-psikhologicheskiy analiz shkol'nykh uchebnykh zadach [Logical and psychological analysis of school training problems]. Moscow: Pedagogika, 1977.

KAMALEEVA, A. R. Primenenie modul'no-kompetentnostnogo podkhoda pri proektirovanii uchebnykh moduley estestvennonauchnykh i professional'nykh distsiplin v organizatsiyakh srednego professional'nogo obrazovaniya [Application of the module-competency-based approach in the design of educational modules for science and professional disciplines in organizations of secondary professional education]. Mezhdunarodnyy zhurnal prikladnykh i fundamental'nykh issledovaniy, v. 9, n. 2, p. 289-294, 2016.

\section{KHUTORSKOY, A.V. Obrazovatel'nye kompetentsii i metodologiya didaktiki}

[Educational competencies and methodology of didactics] Available:

http://khutorskoy.ru/be/2016/0922/index.htm. Access: 10 oct. 2020.

KOSTROVA, Y. S. Prikladnye zadachi po matematike v obuchenii studentov agrovuzov [Application problems in mathematics in agricultural universities]. Molodoy uchenyy, n. 3, p. 931-933, 2014.

KRAEVSKY, V. V. O kul'turologicheskom i kompetentnostnom podkhodakh k formirovaniyu soderzhaniya obrazovaniya [On the culturological and competency-based approaches to the formation of the content of education]. In: ALL-RUSSIAN DISTANCE AUGUST PEDAGOGICAL CONFERENCE, 4., 2005, Moscow. Proceedings [...]. Moscow: Publishing house "Eidos", 2005.

KUDRYAVTSEVA, E. I. Metodologicheskie osnovy izmereniya i otsenki kompetentsiy [Methodological bases of the competencies measurement and evaluation]. In: INTERNATIONAL RESEARCH AND PRACTICE CONFERENCE, 2., 2011, Ekaterinburg. 
Proceedings [...]. Ekaterinburg: Ural. gos. ped un-t, 2011.

LEBEDEV, O. E. Kompetentnostnyy podkhod v obrazovanii [Competency-based approach in education]. Shkol'nye tekhnologii, n. 5, p. 3-12, 2004.

MIKHAYLOVA, I. G. Matematicheskaya podgotovka inzhenera v usloviyakh professional'noy napravlennosti mezhpredmetnykh svyazey [Mathematical training of engineers in the context of a professional focus of interdisciplinary relations]. Tobolsk: Publishing house TGPI, 1998.

MOZHAEV, G. M. Izmerenie i otsenivanie kompetentsiy uchashchikhsya [Measurement and evaluation of students' competencies]. KonTren - Himija dlja vseh. Available: http://www.kontren.narod.ru. Access: 10 dec. 2020.

\section{RUDANETS, N. V. Professional'naya napravlennost' matematiki v sisteme SPO} [Professional focus of mathematics in the system of secondary professional education]. Available: https://videouroki.net/razrabotki/professionalnaya-napravlennost-matematiki-vsisteme-spo.html. Access: 10 dec. 2020.

SIDOROVA, N.V. Osobennosti organizatsii pedagogicheskoy praktikt studentov pri realizatsii kompetentnostnogo podkhoda [Features of the organization of the pedagogical practice of students in the implementation of the competency-based approach]. In: ALLRUSSIAN DISTANCE AUGUST PEDAGOGICAL CONFERENCE, 4., 2005, Ul'yanovsk. Proceedings [...]. Ul'yanovsk: U1GPU, 2005.

TERESHIN, N. A. Prikladnaya napravlennost' shkol'nogo kursa matematiki: Kn. dlya uchashchikhsya [Applied focus of the school course of mathematics: student's book]. Moscow: Prosveshchenie, 1990.

TIKHOMIROV, O. K. Psikhologiya myshleniya [Psychology of thinking]. Moscow: Publishing house of Moscow University, 1984.

ZIMNYAYA, I. A. Klyuchevye kompetentsii - novaya paradigma rezul'tata obrazovaniya [Key competencies: a new paradigm of education results]. Vysshee obrazovanie segodnya, $n$. 5, p. 22-27, 2013.

\section{How to reference this article}

CHEKULAEVA, M. E.; SIDOROVA, N. V.; KUZINA, N. G.; VESELOVSKAYA, J. Application of mathematical problems as means of implementing competency-based approach. Revista on line de Política e Gestão Educacional, Araraquara, v. 25, n. esp. 1, p. 713-725, mar. 2021. e-ISSN:1519-9029. DOI: https://doi.org/10.22633/rpge.v25iesp.1.15008

Submitted: 06/11/2020

Required revisions: $18 / 01 / 2021$

Approved: $23 / 02 / 221$

Published: 01/03/2021 